\title{
Synthesis of 1, 3-diaryl-2-propene-1-one derivatives using Tripotassium phosphate as an alternative and efficient catalyst and study its cytotoxic and antimicrobial properties
}

\author{
Pravinkumar Patil ${ }^{\mathrm{a}}$, Pathan Amjad Khan ${ }^{\mathrm{a}}$ and Sainath Zangade ${ }^{\mathrm{b}^{*}}$
}

${ }^{a}$ Research Laboratory, Department of Chemistry N.E.S. Science College Nanded-431605 (M S), India

${ }^{b}$ Department of Chemistry Madhavrao Patil ACS College Palam Dist. Parbhani-431720 (M S), India

\section{H R O N I C L E}

Article history:

Received October 26, 2019

Received in revised form

February 25, 2020

Accepted March 23, 2020

Available online

March 23, 2020

Keywords:

Synthesis

Chalcones

Tripotassium phosphate

2-Methoxyethanol

Cytotoxic activity

Antimicrobial activity

\begin{abstract}
A B S T R A C T
A series of fourteen chalcone was synthesized via. Claisen-Schmidt condensation between substituted 2- hydroxyl acetonaphthones and substituted benzaldehyde in presence of tripotassium phosphate $\left(\mathrm{K}_{3} \mathrm{PO}_{4}\right)$ catalyst. The reaction was carried out by conventional method using 2methoxyethanol. The procedure is simple and efficient in terms of reaction time, easy workup and isolation of products and yields. In-vitro all these synthesized compounds were screened and evaluated for the cytotoxic and antimicrobial activity. It was found that these compounds had significant cytotoxic activity in comparison with standard 5-flurouracil. The compounds $3 \mathrm{a}, 3 \mathrm{~b}, 3 \mathrm{~h}$, $3 \mathrm{f}$ and 31 were screened by MTT assay against liver cancer cell line-HepG2. Among these, the compound $\mathbf{3 b}$ and $\mathbf{3 c}$ showed LC50 values of $997.14 \mu \mathrm{M} / \mathrm{ml}$ and $284.13 \mu \mathrm{M} / \mathrm{ml}$., respectively. The remaining compounds did not display the LC50 values. The compound 31 displayed the strongest cytotoxic activities with IC50 value of $91.85 \mu \mathrm{g} / \mathrm{ml}$ against liver cancer cell line. The Chalcone 3a, 3f, $\mathbf{3 h}$ and $\mathbf{3 e}$ demonstrated excellent antimicrobial activity and the remaining were moderately active against tested pathogens. The antimicrobial effects of all the tested compounds are due to the presence of pharmacological active substituent in the basic nucleus of Chalcones. Therefore, the present study leads to the development of new class of anticancer and antimicrobial inhibitory candidates.
\end{abstract}

(C) 2020 Growing Science Ltd. All rights reserved.

\section{Introduction}

$\alpha, \beta$-unsaturated carbonyl systems are commonly known as Chalcones. These are some important naturally occurring flavonoids in many plants or are synthetically prepared ${ }^{1}$. They are biogenic key precursors of flavonoids in many plants ${ }^{2,3}$. They also exhibit the wide range of biological properties such as antiviral, anti-inflammatory, antimicrobial ${ }^{4,5}$, cytotoxicity ${ }^{6-8}$, analgesic, antimitotic, antitumor, antiulcerative and antipyretic properties ${ }^{9}$.The $\alpha, \beta$-unsaturated ketones, possess reactive ketoethylenic group, which makes it enormous important in organic synthesis. In addition, these compounds are useful as intermediates for the synthesis of various heterocyclic compounds ${ }^{10}$. They also helpful in material science field viz. non-linear optics, optical limiting, electrochemical sensing, Langmuir films and photo initiated polymerization.

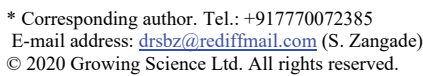


Useful and known method for the preparation of chalcones is the condensation of acetophenones with aldehydes in the presence of the alkali. Claisen-Schmidt condensation is the classical method in which aldehydes reacted with ketone in presence of aqueous alkaline bases ${ }^{11}$, barium hydroxide or Lithium hydroxide ${ }^{12}$. Chalcone synthesis also achieved by various methods by using microwave irradiation $^{13-15}$, ultrasound irradiation ${ }^{16}$, grinding technique ${ }^{17-20}$, Suzuki reaction ${ }^{21}$ and by using diverse catalyst like anhydrous $\mathrm{K}_{2} \mathrm{CO}_{3}{ }^{9}, \mathrm{NaOH}-\mathrm{Al}_{2} \mathrm{O}_{3}{ }^{1}, \mathrm{SOCl}_{2}{ }^{22}$, $\mathrm{KF}$ / natural phosphate ${ }^{23}$, Potassium phosphate ${ }^{24}, \mathrm{CaO}, \mathrm{NH}_{4} \mathrm{OH}^{25}, \mathrm{Na}_{2} \mathrm{CO}_{3}{ }^{26}$, natural phosphate/lithium nitrate ${ }^{27}$, silica-sulphuric $\operatorname{acid}^{28}$, Iodine ${ }^{29}, \mathrm{NaOH}^{30-31}$ and $\mathrm{KOH}^{32}$.

Commercially available $\mathrm{K}_{3} \mathrm{PO}_{4}$ is found to be interesting catalyst for the synthesis of titled compounds since this is thermally stable and inexpensive ${ }^{24}$. In view of these observations, herein for the first time we introduce a simple and convenient approach for chalcone synthesis using tripotassium phosphate in combination with 2-methoxyethanol as reaction solvent (Scheme 1, Table 5).

\section{Results and Discussion}

\subsection{Chemistry}

Tripotassium phosphate is capable of catalyzing the aldol condensation and Claisen-Schimdt reaction. In model reaction, anhydrous tripotassium phosphate catalyzed claisen-schimdt condensation between different substituted 2-acetyl-1-naphthol and substituted benzaldehyde was carried out (Scheme 1, Table 5). Optimization of reaction conditions is of importance for the synthesis of titled compounds. The type of solvent was investigated and the reaction was performed by using various solvent such as $\mathrm{MeOH}, \mathrm{EtOH}, \mathrm{AcOH}, \mathrm{DMSO}, \mathrm{DMF}$, acetonitrile and 2-methoxyethanol. To study the effectiveness of $\mathrm{K}_{3} \mathrm{PO}_{4}$ using different reaction solvent, we performed the experiment in which mixture of substituted 2-hydroxy acetonaphthone ( 0.01 moles) and substituted benzaldehyde $(0.01$ moles) was dissolved in $\mathrm{MeOH}$, EtOH, AcOH, DMSO, DMF, acetonitrile and 2-methoxyethanol. Weighed accurately and transferred 0.02 mole $(4.24 \mathrm{~g})$ of anhydrous $\mathrm{K}_{3} \mathrm{PO}_{4}$ into each reaction solution. The reaction mixture was refluxed till the completion and progress of the reaction as monitored by TLC in Hexane: Ethyl acetate (4:1). In light of the above experiment, we found that 2-methoxyethanol as an efficient reaction medium in terms of clean reactions, inexpensive and ecofriendly. The comparison and optimization using various reaction solvent for synthesis of Chalcones is made in terms of reaction time and yields (Table 6, Fig.3). The combination of 2-methoxyethanol and $\mathrm{K}_{3} \mathrm{PO}_{4}$ found to be convenient route for the preparation of Chalcones. Structures of all newly synthesized chalcones were confirmed by the spectral analysis like FTIR, ${ }^{1} \mathrm{H}$ NMR, $\mathrm{C}^{13} \mathrm{NMR}$,Mass and elemental analysis. FTIR analysis was performed by potassium bromide pellet technique. All the spectra showed the characteristic bands at $3234-3438 \mathrm{~cm}^{-1}, 1617-1634 \mathrm{~cm}^{-1}$ and $1490-1607 \mathrm{~cm}^{-1}$ for the corresponding $\mathrm{OH}, \mathrm{C}=\mathrm{O}$ and aromatic $\mathrm{C}=\mathrm{C}$ bond stretch respectively. ${ }^{1} \mathrm{H}$ NMR was performed on spectrometer at 500 $\mathrm{MHz}$, spectra showed the characteristic singlet at $\delta(13.90-16.00)$, doublet at $\delta\left(6.50-7.70, J=16 \mathrm{~Hz}_{\mathrm{z}}\right)$ and multiplet at $\delta$ (7.50-8.70) for phenolic, $\alpha-\beta$ olefinic and aromatic protons respectively. Mass spectrometric analysis was performed on the LCMS, each spectrum showed the characteristic molecular in peak at respective molecular mass of compound. These results are in confirmation with the formation of product.

\subsection{Cytotoxic activity}

These synthesized compounds were screened for the cytotoxic activity in terms of their ability to fatal the live cells of organism Artemia salina. Cytotoxic activity was evaluated in percentage mortality. In-vitro assay was performed with treatment of different sample concentration $1 \mu \mathrm{M} / \mathrm{ml}, 10 \mu \mathrm{M} / \mathrm{ml}$, $100 \mu \mathrm{M} / \mathrm{ml}$ and $1000 \mu \mathrm{M} / \mathrm{ml}$ on the 10 shrimps of live cells of Artemia salina. Blank and test solutions were incubated at room temperature $\left(28^{\circ} \mathrm{C}-30^{\circ} \mathrm{C}\right)$ under the condition of strong aeration for 24 hours. Percentage mortality was determined by measuring the viable count in the stem of capillary against 
light background. All the compounds were showed the significant cytotoxic activity (Table 1). Compounds $\mathbf{3 b}$ and $\mathbf{3 c}$ were showed the LC50 values.

Percentage mortality $=($ Total nauplii - alive nauplii/total nauplii $) \times 100$

From the Table 1, we have observed that all the compounds demonstrated the significant cytotoxic activity in terms of the \% mortality of live cells of organism Artemia salina. The compounds $\mathbf{3 b}$ and 3c represented the $997.14 \mu \mathrm{M} / \mathrm{ml}$ and $284.13 \mu \mathrm{M} / \mathrm{ml}$ LC50 values, respectively. These values indicate that $\mathbf{3 b}$ and $\mathbf{3 c}$ were more potent than other compounds. The compounds $\mathbf{3 b}$ and $\mathbf{3} \mathbf{c}$ had $-\mathrm{Cl}$ and $-\mathrm{OH}$ substituent at para position of benzene ring. From this observation, it can be concluded that substituent $-\mathrm{Cl}$ and $-\mathrm{OH}$ at para position of benzene ring leads the significant cytotoxic activity.

Table 1. Cytotoxic activity in terms of Percentage mortality

\begin{tabular}{|c|c|c|c|c|c|}
\hline \multirow[t]{2}{*}{ Compound } & \multicolumn{4}{|c|}{$\begin{array}{l}\text { (\%)Percentage Mortality } \\
\text { Sample Concentration }(\mu \mathrm{M} / \mathrm{ml})\end{array}$} & \multirow[t]{2}{*}{ LC50 Value $(\mu \mathrm{M} / \mathrm{ml})$} \\
\hline & 1 & 10 & 100 & 1000 & \\
\hline $3 a$ & 70 & 70 & 80 & 80 & ND \\
\hline $3 b$ & 30 & 40 & 40 & 50 & 997.14 \\
\hline $3 c$ & 40 & 30 & 60 & 70 & 284.13 \\
\hline $3 d$ & 90 & 100 & 100 & 100 & ND \\
\hline $3 e$ & 90 & 90 & 100 & 100 & ND \\
\hline $3 f$ & 90 & 90 & 100 & 100 & ND \\
\hline $3 g$ & 90 & 90 & 100 & 100 & ND \\
\hline $3 \mathrm{~h}$ & 90 & 80 & 100 & 100 & ND \\
\hline $3 i$ & 90 & 90 & 100 & 100 & ND \\
\hline $3 \mathrm{j}$ & 90 & 90 & 100 & 100 & ND \\
\hline $3 \mathrm{k}$ & 90 & 100 & 100 & 100 & ND \\
\hline 31 & 100 & 100 & 100 & 100 & ND \\
\hline $3 \mathrm{~m}$ & 100 & 90 & 100 & 100 & ND \\
\hline $3 n$ & 90 & 100 & 100 & 100 & ND \\
\hline
\end{tabular}

ND-Not detected

\subsection{MTT Assay of compounds $\mathbf{3 a}, \mathbf{3 b}, \mathbf{3 f}, \mathbf{3 h}$ and $\mathbf{3 l}$.}

The growth inhibitory activity of intended compounds against liver cancer cells (HepG2) was evaluated in-vitro by MTT assay. As presented in Fig.1, all compounds displayed inhibitory activity against liver cancer cell. The IC 50 values for compounds $\mathbf{3 a}, \mathbf{3 b}, \mathbf{3 f}, \mathbf{3 h}$ and $\mathbf{3 l}$ were represented in Table 2. It was observed that compound $\mathbf{3 b}, \mathbf{3 f}$ and $\mathbf{3 l}$ were shown $416.66 \mu \mathrm{g} / \mathrm{ml}, 536.66 \mu \mathrm{g} / \mathrm{ml}$ and $91.85 \mu \mathrm{g} / \mathrm{ml}$ $\mathrm{IC}_{50}$ values, respectively (Table 2 ). The compound $\mathbf{3 b}$ has $-\mathrm{Cl}$ substituent at para position, $\mathbf{3 h}$ has $2 \mathrm{Cl}$ substituent at meta and para position and $3 \mathrm{I}$ has $-2 \mathrm{OH}$ substituent at meta and para position of benzene ring. From this observation, it can be concluded that the substituent $-\mathrm{Cl}$ and $-\mathrm{OH}$ at para position of benzene ring leads to the significant potency.

Table 2. The IC50 values of compound 3a, 3b, 3f, 3h and 31 against liver cancer cell line

\section{Compound \\ $(\mathrm{IC50}, \boldsymbol{\mu g} / \mathrm{ml})$}

In vitro inhibition of liver cancer cell (HepG2)

$\begin{array}{cc}\text { Standard 5-flurouracil } & 97.75 \\ \text { 3a } & >1000 \\ \text { 3b } & 416.66 \\ \text { 3f } & >1000 \\ \text { 3h } & 536.66 \\ 31 & 91.85\end{array}$




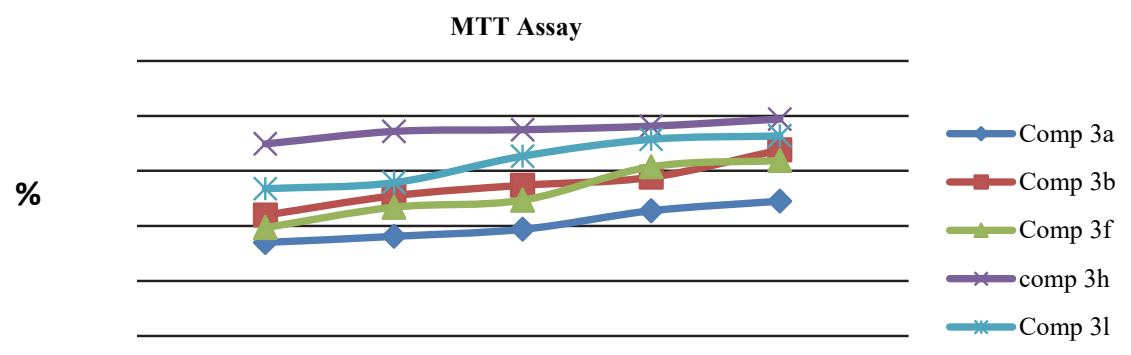

Sample concentrations in $\mu \mathrm{g} / \mathrm{ml}$

Fig.1. Inhibitory activity of compounds $\mathbf{3 a}, \mathbf{3 b}, \mathbf{3 f}, \mathbf{3 h}$ and $\mathbf{3 l}$ on liver cancer cell was incubated with indicated concentrations for $24 \mathrm{~h}$.

\subsection{Antimicrobial activity}

Table 3.Activity index of the compounds (3a-3n)

$\frac{\text { Antibacterial }}{\text { Gram positive bacteria } \quad \text { Gram negative bacteria }}$ Antifungal

\begin{tabular}{|c|c|c|c|c|c|c|}
\hline \multirow{2}{*}{ Compound } & \multicolumn{2}{|c|}{ S.aureus } & \multicolumn{2}{|c|}{ E.coli } & \multicolumn{2}{|c|}{ C.albicans } \\
\hline & $\begin{array}{c}\text { Mean } \\
\text { value of } \\
\text { Zone of } \\
\text { inhibition } \\
\text { (in mm) }\end{array}$ & $\begin{array}{l}\text { Activity } \\
\text { Index } \\
\text { (A.I.) }\end{array}$ & $\begin{array}{l}\text { Mean value } \\
\text { of Zone of } \\
\text { inhibition } \\
\text { (in mm) }\end{array}$ & $\begin{array}{l}\text { Activity } \\
\text { Index } \\
\text { (A.I.) }\end{array}$ & $\begin{array}{c}\text { Mean } \\
\text { value of } \\
\text { Zone of } \\
\text { inhibition } \\
\text { (in mm) }\end{array}$ & $\begin{array}{l}\text { Activity } \\
\text { Index } \\
\text { (A.I.) }\end{array}$ \\
\hline $3 a$ & 21.55 & 1.2471 & 15.17 & 0.8358 & 17.45 & 1.03132 \\
\hline $3 b$ & 10.22 & 0.5914 & 15.88 & 0.8749 & 13.95 & 0.82447 \\
\hline $3 c$ & 13.36 & 0.7731 & 13.19 & 0.7267 & 11.29 & 0.66726 \\
\hline $3 d$ & 11.39 & 0.6591 & 12.09 & 0.6661 & 16.12 & 0.95272 \\
\hline $3 e$ & 13.9 & 0.8044 & 12.44 & 0.6854 & 11.93 & 0.70508 \\
\hline $3 f$ & 14.05 & 0.8131 & 12.67 & 0.6981 & 14.6 & 0.86288 \\
\hline $3 g$ & 12.25 & 0.7089 & 14.04 & 0.7736 & No zone & - \\
\hline $3 \mathrm{~h}$ & 13.55 & 0.7841 & 15.08 & 0.8309 & 14.25 & 0.84220 \\
\hline $3 \mathrm{i}$ & 11.2 & 0.6481 & 11.77 & 0.6485 & No zone & - \\
\hline $3 \mathrm{j}$ & 10.23 & 0.5920 & 12.39 & 0.6826 & 13.02 & 0.76950 \\
\hline $3 \mathrm{k}$ & 11.15 & 0.6453 & 12.32 & 0.6788 & No zone & - \\
\hline 31 & 14.2 & 0.8218 & 12.88 & 0.7096 & 13.04 & 0.77069 \\
\hline $3 \mathrm{~m}$ & 12.93 & 0.7483 & 10.19 & 0.5614 & 13.87 & 0.81974 \\
\hline $3 n$ & 13.08 & 0.7569 & 11.55 & 0.6364 & 13.86 & 0.81915 \\
\hline DMSO & No zone & - & No zone & - & No zone & - \\
\hline $\begin{array}{l}\text { Ampicilin } \\
\text { Standard }\end{array}$ & 17.28 & - & 18.15 & - & - & - \\
\hline $\begin{array}{l}\text { Fluconazole } \\
\text { Standard }\end{array}$ & -- & - & --- & - & 16.92 & - \\
\hline
\end{tabular}


These synthesized compounds were screened for the antibacterial activities against Gram positive bacteria Staphylococcus aureus (ATCC6538) and Gram negative bacteria Echerchia coli (ATCC8739) and were screened for antifungal activity against Candida albicans (ATCC10231) by Agar cup method. Standard drugs Ampicilin and Fluconazole were used as antibacterial and antifungal drug for results comparison. Two bacterial stains were incubated for $24 \mathrm{hr}$ at $35^{\circ} \mathrm{C}$ and the single fungal stain was incubated for $48 \mathrm{hr}$ at $25^{\circ} \mathrm{C}$ along with antibacterial and antifungal standard. For antibacterial and antifungal screening, culture medium was soyabean casein digest agar and sabourauds dextrose agar respectively. Stock solution $(1 \mathrm{mg} / \mathrm{ml})$ was prepared by dissolving compound in dimethylsulfoxide. All the studies were carried out in triplicates and average zone was reported in final reading. The activity index (A.I.) of all the compounds is calculated by following formula, the results are summarised in Table 3 and the average zone of inhibition against the pathogens is graphically presented in Fig.2.

$$
\text { Activity Index (A.I.) }=\frac{\text { Mean zone of inhibition of derivatives }}{\text { Zone of inhibition of Standard drug }}
$$

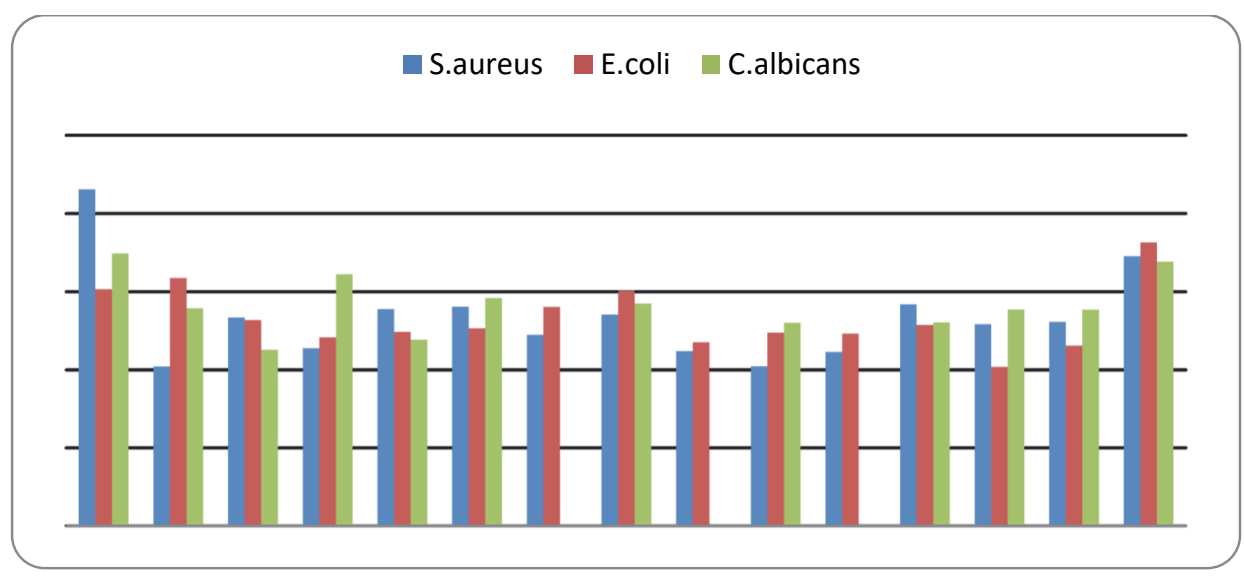

Fig. 2. Zone of inhibition of compounds against pathogens

From Table 3, various observations are drawn, the compounds $\mathbf{3 a}, \mathbf{3 f}, \mathbf{3 h}$ and $\mathbf{3 e}$ were shown the significant antibacterial and antifungal activity against the Staphylococcus aureus, Echerchia coli and Candida albicans respectively. The compound 3a is bearing the 2-OH and -3I substituent, $\mathbf{3 f}$ and $\mathbf{3 h}$ are bearing $-\mathrm{Br},-2 \mathrm{Cl}$ substituent whereas $3 \mathrm{e}$ possess the $-\mathrm{Br}$ and $2-\mathrm{OH}$ substituent. These observed results support the structure activity relationship at the varying structural features of the molecules. The presence of multiple hydroxyl and halogen substituent in compounds $\mathbf{3 a}, \mathbf{3 f}, \mathbf{3 h}$ and $\mathbf{3 e}$ lead to the significant antimicrobial activity. The compound $3 \mathrm{j}$ contains $-2 \mathrm{Br}$ substituent, it showed moderate antibacterial activity against Echerchia coli. The compounds $\mathbf{3 b}$ and $\mathbf{3 g}$ associated with $-\mathrm{Br},-\mathrm{Cl}$ and $\mathrm{Br},-\mathrm{OH}$ substituent respectively, they showed moderate antibacterial activity against Echerchia coli. Also the compounds $3 \mathbf{i}$ and $3 \mathbf{k}$ associated with $-\mathrm{Br},-\mathrm{NO}_{2},-\left(\mathrm{CH}_{3}\right)_{2}$ substituent showed good antibacterial activity instead did not show the antifungal activity. Activity index of all the compounds is summarized in the Table 3.

\subsubsection{Minimum inhibitory concentration (MIC)}

The minimum inhibitory concentration of synthesized chalcones were performed at the concentrations 1.0, 0.5, 0.25 and $0.12 \mathrm{mg} / \mathrm{ml}$, the results of MIC are given in Table 4. From the table, it looks that the compound 3a showed the best minimum inhibitory concentrations $(0.12 \mathrm{mg} / \mathrm{ml})$ against the antibacterial and antifungal organisms. The compound $\mathbf{3 b}$ and $\mathbf{3 h}$ showed better MIC $0.50 \mathrm{mg} / \mathrm{ml}$, $0.25 \mathrm{mg} / \mathrm{ml}$ and $0.25 \mathrm{mg} / \mathrm{ml}$ against Staphylococcus aureus, Echerchia coli and Candida albicans respectively. Also, the compound $\mathbf{3 f}$ showed the moderate MIC $0.25 \mathrm{mg} / \mathrm{ml}, 0.50 \mathrm{mg} / \mathrm{ml}$ and 0.25 
$\mathrm{mg} / \mathrm{ml}$ against antibacterial and antifungal organisms. The compounds $\mathbf{3 i}$ and $\mathbf{3 k}$ showed the good MIC $1.0 \mathrm{mg} / \mathrm{ml}$ against the antibacterial organisms (Table 4). From the comparative study, it is revealed that the compounds bearing the multiple halogen and hydroxyl groups have moderate inhibition activity, however compounds bearings nitro, methoxy groups reduce the inhibition activity.

Table 4. MICs of chalcone derivatives (3a-3n)

\begin{tabular}{|c|c|c|c|c|c|c|c|c|c|c|c|c|}
\hline \multirow{4}{*}{ Compound } & \multicolumn{8}{|c|}{ Antibacterial } & \multirow{2}{*}{\multicolumn{4}{|c|}{ Antifungal }} \\
\hline & \multirow{2}{*}{\multicolumn{4}{|c|}{$\begin{array}{c}\text { Gram positive bacteria } \\
\text { S.aureus }\end{array}$}} & \multirow{2}{*}{\multicolumn{4}{|c|}{$\begin{array}{c}\text { Gram negative bacteria } \\
\text { E.coli }\end{array}$}} & & & & \\
\hline & & & & & & & & & & C.a & icans & \\
\hline & 1.0 & 0.5 & 0.25 & 0.12 & 1.0 & 0.5 & 0.25 & 0.12 & 1.0 & 0.5 & 0.25 & 0.12 \\
\hline $3 a$ & - & - & - & - & - & - & - & + & - & - & - & - \\
\hline $3 b$ & - & - & + & + & - & - & - & + & - & - & - & + \\
\hline $3 c$ & - & + & + & + & - & + & + & + & - & + & + & + \\
\hline $3 d$ & - & + & + & + & - & + & + & + & - & - & - & + \\
\hline $3 e$ & - & - & + & + & - & + & + & + & - & + & + & + \\
\hline $3 f$ & - & - & - & + & - & - & + & + & - & - & - & + \\
\hline $3 g$ & - & + & + & + & - & - & + & + & + & + & + & + \\
\hline $3 h$ & - & - & + & + & - & - & - & + & - & - & - & + \\
\hline $3 \mathrm{i}$ & - & + & + & + & - & + & + & + & + & + & + & + \\
\hline $3 \mathrm{j}$ & - & + & + & + & - & + & + & + & - & + & + & + \\
\hline $3 \mathrm{k}$ & - & + & + & + & - & + & + & + & + & + & + & + \\
\hline 31 & - & - & - & + & - & - & + & + & - & - & + & + \\
\hline $3 \mathrm{~m}$ & - & + & + & + & - & + & + & + & - & - & - & + \\
\hline $3 n$ & - & + & + & + & - & + & + & + & - & - & - & + \\
\hline $\begin{array}{l}\text { Ampicilin } \\
\text { Standard }\end{array}$ & - & - & - & + & - & - & - & + & & & & \\
\hline $\begin{array}{c}\text { Fluconazole } \\
\text { Standard }\end{array}$ & & & & & & & & & + & + & + & + \\
\hline
\end{tabular}

The positive sign (+) indicate growth on plate, negative sign (-) indicate no growth on plate.

\section{Conclusions}

In present study, we have developed method using tripotassium phosphate as an efficient green catalyst for the synthesis of chalcones. Tripotassium phosphate is nontoxic, cheaper and economic. It provides greater reaction conditions coupled with clean products, increased yield and better economy. Newly synthesized compounds were characterized by IR, ${ }^{1} \mathrm{H}$ NMR, $\mathrm{C}^{13} \mathrm{NMR}$, mass spectral data and elemental analysis. All results are in agreement with the structural confirmation. These compounds were screened for their antimicrobial activity. Antimicrobial activity was studied against the gram positive bacteria Staphylococcus aureus and gram negative bacteria Echerchia coli and antifungal pathogen Candida albicans with MICs of $0.12,0.25,0.50$ and $1.0 \mathrm{mg} / \mathrm{ml}$. From the antimicrobial study, it was concluded that the compounds $\mathbf{3 a}, \mathbf{3 f}, \mathbf{3 h}$ and $\mathbf{3 e}$ having multiple halogen and hydroxyl substituent show significant antibacterial activity. The synthesized compounds were screened for cytotoxic activity against the organism Artemia salina. They showed significant cytotoxic activity. Further, the compounds $\mathbf{3 a}, \mathbf{3 b}, \mathbf{3 f}, \mathbf{h}$ and $\mathbf{3 l}$ were evaluated for anticancer activity by MTT assay against the liver cancer cell (Hep G2). The compounds $\mathbf{3 b} \mathbf{b} \mathbf{3}$ and $\mathbf{3 l}$ represented significant anticancer activity. They have chloro and hydroxyl substituent at para position of benzene ring. These studies reveal the antimicrobial and anticancer potency of the 1,3-diaryl-2-propene-1-one derivatives.

\section{Acknowledgements}

The authors are very thankful to Panjab University, Chandigarh for Instrumental Analysis and Radial Microbiotech services for biological activities. 


\section{Experimental}

\subsection{Materials and Methods}

Starting material alpha naphthol, all the aldehydes, solvents were purchased from the Loba chemicals. Zinc chloride and tripotassium phosphate was purchased from the Sigma Aldrich chemicals and were used without purification. TLC plate, Silica gel $60 \mathrm{~F}_{254}$, Aluminum backed was purchased from the Merck. The progress of the reaction was monitored by TLC. Acetyl naphtol was synthesized by the acylation reaction of alpha naphthol in presence of zinc chloride and acetic acid solvent. Halo ketones were prepared from alpha naphthol according to literature procedure ${ }^{33-35}$. Melting points were determined in open glass capillaries on Veego, VMP-D, Melting Point System, are uncorrected. FTIR spectra were recorded as KBr pellets on a Perkin Elmer System 2000 and Shimadzu spectrophotometer. ${ }^{1} \mathrm{H}$ and ${ }^{13} \mathrm{C}$ NMR spectra were acquired on a Bruker Avance NEO500 Spectrometer at $500 \mathrm{MHz}$. Mass spectra were recorded on LCMS.

\subsection{General Procedure for Synthesis of 1, 3-diaryl-2-propene-1-one}

A mixture of substituted 2-hydroxy acetonaphthone ( 0.01 moles) and substituted benzaldehyde ( 0.01 moles) were dissolved in $20 \mathrm{ml}$ of 2-methoxyethanol. Weighed accurately and transferred 0.02 mole $(4.24 \mathrm{~g})$ of anhydrous $\mathrm{K}_{3} \mathrm{PO}_{4}$ in to reaction solution. The reaction mixture was refluxed for 5 hours and progress of the reaction was monitored by TLC in Hexane: Ethyl acetate (4:1). After completion of refluxing, reaction mixture was cooled and poured into $20 \mathrm{ml}$ of ice-water, stirred then treated with dil. $\mathrm{HCl}$ to precipitate crude solid product. Solid mass observed were filtered, washed with sufficient amount of water and dried under vacuum. The crude product was purified by column chromatography to give pure sample.

\subsection{Column Chromatography}

Silica gel was used as stationary phase and a mixture of hexane and ethyl acetate was used as mobile phase in the proportion 8:2. Initially weighed the $20 \mathrm{~g}$ of silica gel in the beaker and prepared the slurry in hexane. The bottom of the column was plugged with a piece of glass wool just above the stopcock. Slurry was transferred gradually in the column through funnel, ensured that column packing should be free from gap. Solvent was allowed to drain until just before the silica gel and the solvent front meet. $100 \mathrm{mg}$ of sample was dissolved in $1 \mathrm{ml}$ of ethyl acetate. Added sample solution on the top of column using pipette. Remainder of the column was filled with $4.0 \mathrm{ml}$ of hexane. Stopcock was opened gradually and flow rate was adjusted as a single drop per 30 seconds to achieve well separation of mixture. $2.0 \mathrm{ml}$ of fractions were collected in each test tube. Additionally mobile phase was used until the desired compounds have been eluted. The test tube was identified by using TLC that contains desired product and then mixed all of the same fractions. The solvent was evaporated to get isolated pure product. The structures of products were confirmed by the physical and spectral characterization.

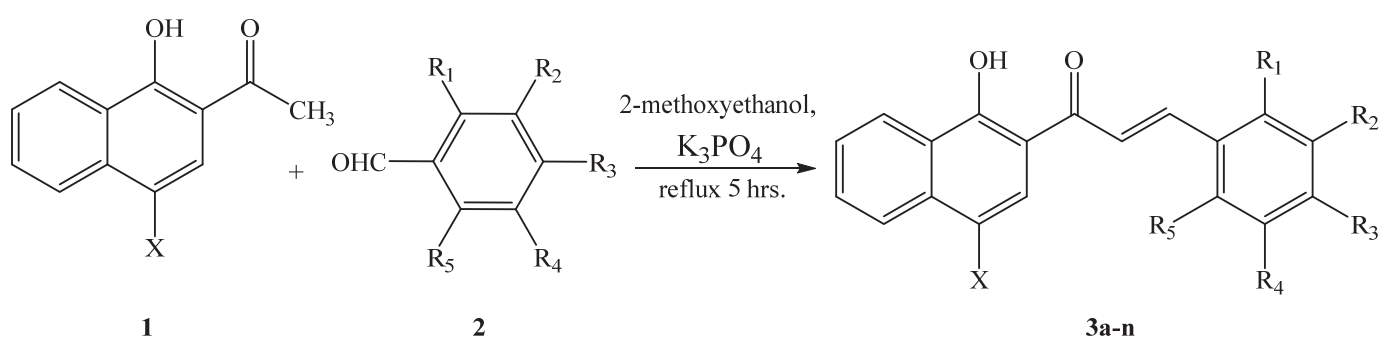

Tripotassium phosphate supported basic catalyst for synthesis of Chalcones 
Table 5. Synthesis of chalcone (3a-3n)

\begin{tabular}{cccccccc}
\hline Sr.No & Compound & $\mathbf{X}$ & $\mathbf{R}_{\mathbf{1}}$ & $\mathbf{R}_{\mathbf{2}}$ & $\mathbf{R}_{\mathbf{3}}$ & $\mathbf{R}_{\mathbf{4}}$ & $\mathbf{R}_{\mathbf{5}}$ \\
\hline 1 & $3 \mathrm{a}$ & $\mathrm{I}$ & $\mathrm{OH}$ & $\mathrm{I}$ & $\mathrm{H}$ & $\mathrm{I}$ & $\mathrm{H}$ \\
2 & $3 \mathrm{~b}$ & $\mathrm{Br}$ & $\mathrm{H}$ & $\mathrm{H}$ & $\mathrm{C}$ & $\mathrm{H}$ & $\mathrm{H}$ \\
3 & $3 \mathrm{c}$ & $\mathrm{Br}$ & $\mathrm{H}$ & $\mathrm{H}$ & $\mathrm{OCH}_{3}$ & $\mathrm{H}$ & $\mathrm{H}$ \\
4 & $3 \mathrm{~d}$ & $\mathrm{Br}$ & $\mathrm{H}$ & $\mathrm{OCH}_{3}$ & $\mathrm{OH}$ & $\mathrm{H}$ & $\mathrm{H}$ \\
5 & $3 \mathrm{e}$ & $\mathrm{Br}$ & $\mathrm{H}$ & $\mathrm{H}$ & $\mathrm{Br}$ & $\mathrm{H}$ & $\mathrm{H}$ \\
6 & $3 \mathrm{f}$ & $\mathrm{Br}$ & $\mathrm{Cl}$ & $\mathrm{H}$ & $\mathrm{H}$ & $\mathrm{H}$ & $\mathrm{Cl}$ \\
7 & $3 \mathrm{~g}$ & $\mathrm{Br}$ & $\mathrm{H}$ & $\mathrm{H}$ & $\mathrm{OH}$ & $\mathrm{H}$ & $\mathrm{H}$ \\
8 & $3 \mathrm{~h}$ & $\mathrm{Br}$ & $\mathrm{Cl}$ & $\mathrm{H}$ & $\mathrm{Cl}$ & $\mathrm{H}$ & $\mathrm{H}$ \\
9 & $3 \mathrm{i}$ & $\mathrm{Br}$ & $\mathrm{H}$ & $\mathrm{H}$ & $\mathrm{NO}_{2}$ & $\mathrm{H}$ & $\mathrm{H}$ \\
10 & $3 \mathrm{j}$ & $\mathrm{Br}$ & $\mathrm{H}$ & $\mathrm{H}$ & $\mathrm{F}$ & $\mathrm{H}$ & $\mathrm{H}$ \\
11 & $3 \mathrm{k}$ & $\mathrm{Br}$ & $\mathrm{H}$ & $\mathrm{H}$ & $\mathrm{N}^{\left(\mathrm{CH}_{3}\right)_{2}}$ & $\mathrm{H}$ & $\mathrm{H}$ \\
12 & 31 & $\mathrm{Br}$ & $\mathrm{H}$ & $\mathrm{OH}$ & $\mathrm{OH}$ & $\mathrm{H}$ & $\mathrm{H}$ \\
13 & $3 \mathrm{~m}$ & $\mathrm{I}$ & $\mathrm{H}$ & $\mathrm{OCH}_{3}$ & $\mathrm{OCH}_{3}$ & $\mathrm{H}$ & $\mathrm{H}$ \\
14 & $3 \mathrm{n}$ & $\mathrm{I}$ & $\mathrm{H}$ & $\mathrm{OH}$ & $\mathrm{OH}^{2}$ & $\mathrm{H}$ & $\mathrm{H}$ \\
\hline
\end{tabular}

Table 6. Optimization of reaction condition for chalcone synthesis

\begin{tabular}{ccccc}
\hline Entry & Solvent & Quantity (ml) & Time (h) & Yield (\%) \\
\hline 1 & Methanol & 40 & 10 & 52 \\
2 & Ethanol & 35 & 9.0 & 66 \\
3 & Acetic acid & 35 & 10.5 & 59 \\
4 & DMSO & 30 & 8.0 & 62 \\
5 & DMF & 30 & 8.5 & 63 \\
6 & Acetonitrile & 25 & 7.0 & 57 \\
7 & 2-Methoxy ethanol & 20 & 5.0 & 81 \\
\hline
\end{tabular}

— Time (h) $\quad$-Yield (\%)

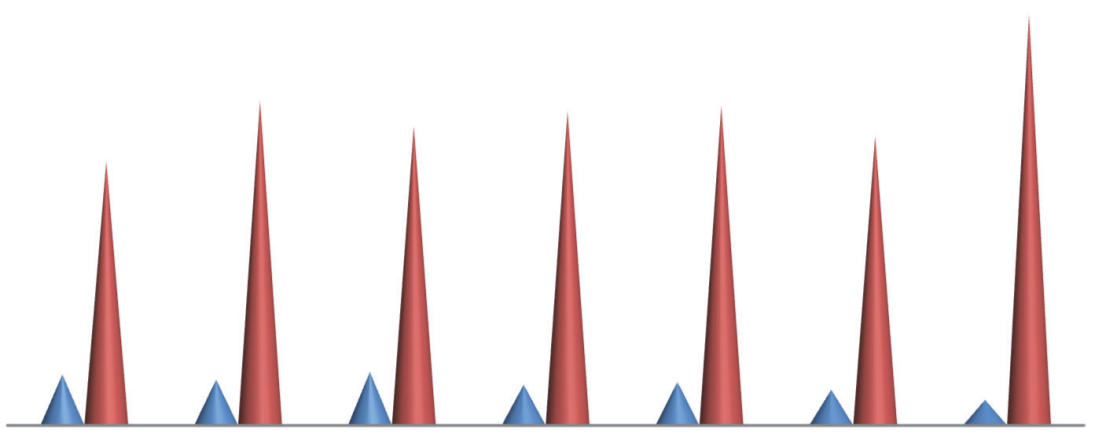

Fig. 3. Optimization of reaction condition for chalcone synthesis

\subsection{Physical and Spectral Data}

The synthesized compounds were purified by column chromatography. All the compounds were colored in nature. The compounds were dried; finely powdered and melting points were recorded. FTIR analysis was performed by potassium bromide pellet technique. All the spectra showed the characteristic bands at $3234-3438 \mathrm{~cm}^{-1}, 1617-1634 \mathrm{~cm}^{-1}$ and $1490-1607 \mathrm{~cm}^{-1}$ for the corresponding $\mathrm{OH}, \mathrm{C}=\mathrm{O}$ and aromatic $\mathrm{C}=\mathrm{C}$ bond stretch respectively. ${ }^{1} \mathrm{H}$ NMR was performed on spectrometer at 500 $\mathrm{MHz}$, spectra showed the characteristic singlet at $\delta(13.90-16.00)$, doublet at $\delta\left(6.50-7.70, J=16 \mathrm{H}_{\mathrm{z}}\right)$ and 
multiplet at $\delta$ (7.50-8.70) for phenolic, $\alpha-\beta$ olefinic and aromatic protons respectively. $C^{13} \mathrm{NMR}$ was also performed on spectrometer at $500 \mathrm{MHz}$, spectra showed the singlet at $\delta$ (204.00-205.00), multiplet at $\delta(110.00-167.00)$ and singlet at $\delta(55.00-56.00)$ for carbonyl carbon, aromatic carbon and methoxy carbon respectively (Fig.3). Mass spectrometric analysis was performed on the LCMS, each spectra showed the characteristic molecular ion peak at respective molecular mass of compound. Elemental analysis was performed on ThermoFinnigan elemental analyser; obtained values were comparable with the theoretical values. These results are in confirmation with the formation of product. Following are the spectral and physical details of each compound.

\section{3-(2-Hydroxy-3, 5-Diodo-phenyl)-1-(4-Iodo-1-hydroxyl-naphthalen-2-yl)-propenone (3a)}

Brown solid, Yield, $81 \%$.Melting point, $205^{\circ} \mathrm{C} . \mathrm{FTIR}\left(\mathrm{KBr}, \mathrm{cm}^{-1}\right)$ :

3419(OH), 1628(C=O),1577,1540(ring C $=\mathrm{C}),{ }^{1} \mathrm{H}$ NMR (DMSO,500 MHz): $\delta 5.19(\mathrm{~s}, 1 \mathrm{H}, \mathrm{OH}), \delta 6.90(\mathrm{~d}$, $\left.J=16 \mathrm{~Hz} 1 \mathrm{H}, \mathrm{H}_{\alpha}\right), \delta 7.46\left(\mathrm{~d}, J=16 \mathrm{~Hz} 1 \mathrm{H}, \mathrm{H}_{\beta}\right), \delta 7.66-8.37(\mathrm{~m}, 7 \mathrm{H}, \mathrm{Ar}-\mathrm{H}), \delta 13.90(\mathrm{~s}, 1 \mathrm{H}, \mathrm{OH}) .{ }^{13} \mathrm{C}$ NMR (DMSO, 500MHz): $\delta 205.11(\mathrm{C}=\mathrm{O}), \delta 115.57-161.76$ (Aromatic carbon), $\delta 82.87-90.51(\mathrm{C}-\mathrm{I}) . \mathrm{MS}$ $\mathrm{m} / \mathrm{z}: 667\left(\mathrm{M}^{+}\right), 471,385,269,249,181,179$.Anal.Calc for $\mathrm{C}_{19} \mathrm{H}_{11} \mathrm{O}_{3} \mathrm{I}_{3}: \mathrm{C}, 34.13 ; \mathrm{H}, 1.65 ; \mathrm{I}, 57.04$.Found: C,34.18;H,1.72;I,57.11.

\section{3-(4-Chloro-phenyl)-1-(4-Bromo-1-hydroxyl-naphthalen-2-yl)-propenone (3b)}

Yellow solid, Yield, $76 \%$.Melting point, $118^{0} \mathrm{C} . \mathrm{FTIR}\left(\mathrm{KBr}, \mathrm{cm}^{-1}\right)$ : $3415(\mathrm{OH}), 1631(\mathrm{C}=\mathrm{O}), 1577,1490($ ring $\mathrm{C}=\mathrm{C}),{ }_{1}^{1} \mathrm{H}$ NMR(500 MHz,DMSO) $\delta 6.74\left(\mathrm{~d}, J=16 \mathrm{~Hz} 1 \mathrm{H}, \mathrm{H}_{\alpha}\right)$, $\delta 7.54\left(\mathrm{~d}, J=16 \mathrm{~Hz} 1 \mathrm{H}, \mathrm{H}_{\beta}\right), \delta 7.66-8.64(\mathrm{~m}, 9 \mathrm{H}, \mathrm{Ar}-\mathrm{H}), \delta 15.02(\mathrm{~s}, 1 \mathrm{H}, \mathrm{OH}) .{ }^{13} \mathrm{C}$ NMR (DMSO, 500MHz): $\delta 204.98(\mathrm{C}=\mathrm{O}), \delta 114.84-136.17$ (Aromatic carbon, ),MS $\mathrm{m} / \mathrm{z}: 387\left(\mathrm{M}^{+}\right), 375,315,249,181,179$.Anal.Calc for $\mathrm{C}_{19} \mathrm{H}_{12} \mathrm{O}_{2} \mathrm{BrCl}: \mathrm{C}, 58.76 ; \mathrm{H}, 3.09 ; \mathrm{X}(\mathrm{Br}+\mathrm{Cl}), 29.64$.Found: C,58.84; $\mathrm{H}, 3.15 ; \mathrm{X}(\mathrm{Br}+\mathrm{Cl}), 29.72$.

\section{3-(4-methoxy-phenyl)-1-(4-Bromo-1-hydroxyl-naphthalen-2-yl)-propenone (3c)}

Yellow solid, Yield, $84 \%$.Melting point, $166^{0} \mathrm{C} . \mathrm{FTIR}\left(\mathrm{KBr}, \mathrm{cm}^{-1}\right)$ : $3430(\mathrm{OH}), 1630(\mathrm{C}=\mathrm{O}), 1607,1563($ ring $\mathrm{C}=\mathrm{C}),{ }^{1} \mathrm{H}$ NMR(500 MHz,DMSO$) \delta 3.86\left(\mathrm{~s}, 3 \mathrm{H},-\mathrm{OCH}_{3}\right)$, $\delta 7.05\left(\mathrm{~d}, \mathrm{~J}=16 \mathrm{~Hz}_{\mathrm{z}} 1 \mathrm{H}, \mathrm{H}_{\alpha}\right), \delta 7.61\left(\mathrm{~d}, \mathrm{~J}=16 \mathrm{~Hz}_{\mathrm{z}} 1 \mathrm{H}, \mathrm{H}_{\beta}\right), \delta 7.70-8.70(\mathrm{~m}, 9 \mathrm{H}, \mathrm{Ar}-\mathrm{H}), \delta 15.31(\mathrm{~s}, 1 \mathrm{H}, \mathrm{OH}) .{ }^{13} \mathrm{C}$

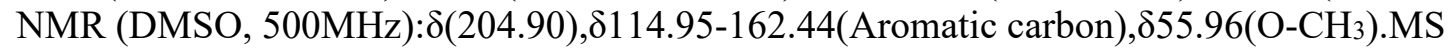
$\mathrm{m} / \mathrm{z}: 383\left(\mathrm{M}^{+}\right), 336,281,255,199,97$.Anal.Calc for $\mathrm{C}_{20} \mathrm{H}_{15} \mathrm{O}_{3} \mathrm{Br}: \mathrm{C}, 62.66 ; \mathrm{H}, 3.92 ; \mathrm{Br}, 20.89$.Found: $\mathrm{C}, 62.74 ; \mathrm{H}, 3.96 ; \mathrm{Br}, 20.92$.

\section{3-(4-Hydroxy-3-methoxy-phenyl)-1-(4-Bromo-1-hydroxyl-naphthalen-2-yl)-propenone (3d)}

Orange solid, Yield, $79 \%$.Melting point, $180^{\circ} \mathrm{C} . \mathrm{FTIR}\left(\mathrm{KBr}, \mathrm{cm}^{-1}\right)$ :

3424(OH), 1627(C=O),1604,1559(ring C=C), ${ }_{1} \mathrm{H}$ NMR(500 MHz,DMSO) $83.91\left(\mathrm{~s}, 3 \mathrm{H},-\mathrm{OCH}_{3}\right)$, $\delta 5.30(\mathrm{~s}, 1 \mathrm{H},-\mathrm{OH}), \delta 6.88(\mathrm{~d}, \mathrm{~J}=16 \mathrm{~Hz} 1 \mathrm{H}, \mathrm{H} \alpha), \delta 7.46\left(\mathrm{~d}, \mathrm{~J}=16 \mathrm{~Hz} 1 \mathrm{H}, \mathrm{H}_{\beta}\right), \delta 7.63-8.67(\mathrm{~m}, 8 \mathrm{H}, \mathrm{Ar}-\mathrm{H})$, $\delta 15.44(\mathrm{~s}, 1 \mathrm{H}, \mathrm{OH}) .{ }^{13} \mathrm{C}$ NMR (DMSO, 500MHz): $\delta 204.55(\mathrm{C}=\mathrm{O}), \delta 110.10-163.63$ (Aromatic carbon), $\delta$ 56.49(O-CH3). $\left(\mathrm{MS} \mathrm{m} / \mathrm{z}: 399\left(\mathrm{M}^{+}\right), 397,385,281,263,181,149,97\right.$.Anal.Calc for $\mathrm{C}_{20} \mathrm{H}_{15} \mathrm{O}_{4} \mathrm{Br}: \mathrm{C}, 60.15 ; \mathrm{H}, 3.76 ; \mathrm{Br}, 20.05$.Found: $\mathrm{C}, 60.23 ; \mathrm{H}, 3.81 ; \mathrm{Br}, 20.10$.

3-(4-Bromo-phenyl)-1-(4-Bromo-1-hydroxyl-naphthalen-2-yl)-propenone (3e):

Brown solid, Yield, $73 \%$.Melting point, $198^{\circ} \mathrm{C}$.FTIR $\left(\mathrm{KBr}, \mathrm{cm}^{-1}\right)$ : 3400(OH), 1624(C=O),1589,1568(ring $\mathrm{C}=\mathrm{C}),{ }^{1} \mathrm{H}$ NMR(500 MHz,DMSO) $\delta 6.78\left(\mathrm{~d}, \mathrm{~J}=16 \mathrm{~Hz}_{\mathrm{z}} 1 \mathrm{H}, \mathrm{H}_{\alpha}\right)$, $\delta 7.46\left(\mathrm{~d}, \mathrm{~J}=16 \mathrm{~Hz} 1 \mathrm{H}, \mathrm{H}_{\beta}\right), \delta 7.69-8.41(\mathrm{~m}, 9 \mathrm{H}, \mathrm{Ar}-\mathrm{H}), \delta 13.98(\mathrm{~s}, 1 \mathrm{H}, \mathrm{OH}) .{ }^{13} \mathrm{C}$ NMR (DMSO, 500MHz): $\delta 205.25(\mathrm{C}=\mathrm{O}), \delta 110.71-167.09$ (Aromatic carbon).MS 
m/z:432(M+1),419,265,263,249,201,157,97,79.Anal.Calc for

$\mathrm{C}_{19} \mathrm{H}_{12} \mathrm{O}_{2} \mathrm{Br}_{2}: \mathrm{C}, 52.78 ; \mathrm{H}, 2.78 ; \mathrm{Br}, 37.04$.Found: C,52.85;H,2.85;Br,37.12.

3-(2, 6-Dichloro-phenyl)-1-(4-Bromo-1-hydroxyl-naphthalen-2-yl)-propenone (3f)

Brown solid, Yield, 79 \%.Melting point, $230^{\circ} \mathrm{C} . \mathrm{FTIR}\left(\mathrm{KBr}, \mathrm{cm}^{-1}\right): 3235(\mathrm{OH}), 1617(\mathrm{C}=\mathrm{O}), 1577,1553$ (ring $\mathrm{C}=\mathrm{C}),{ }^{1} \mathrm{H}$ NMR $(500 \mathrm{MHz}, \mathrm{DMSO}) \delta 6.52\left(\mathrm{~d}, \mathrm{~J}=16 \mathrm{~Hz}_{\mathrm{z}} 1 \mathrm{H}, \mathrm{H}_{\alpha}\right), \delta 7.42\left(\mathrm{~d}, \mathrm{~J}=16 \mathrm{~Hz} 1 \mathrm{H}, \mathrm{H}_{\beta}\right), \delta 7.69-$ 8.40(m,8H,Ar-H), $\delta 14.00(\mathrm{~s}, 1 \mathrm{H}, \mathrm{OH}) .{ }^{13} \mathrm{C}$ NMR (DMSO, 500MHz): $\delta 205.15(\mathrm{C}=\mathrm{O}), \delta 110.61-$ 161.16(Aromatic carbon).MS m/z:422( $\left.\mathrm{M}^{+}\right), 377,325,283,263,255,249,181,97$. Anal.Calc for $\mathrm{C}_{19} \mathrm{H}_{11} \mathrm{O}_{2} \mathrm{BrCl}_{2}: \mathrm{C}, 54.03 ; \mathrm{H}, 2.61 ; \mathrm{X}(\mathrm{Br}+\mathrm{Cl}), 35.78$.Found: $\mathrm{C}, 54.11 ; \mathrm{H}, 2.68 ; \mathrm{X}(\mathrm{Br}+\mathrm{Cl}), 35.84$.

3-(4-Hydroxy-phenyl)-1-(4-Bromo-1-hydroxyl-naphthalen-2-yl)-propenone (3g)

Brown solid, Yield, $77 \%$.Melting point, $215^{\circ} \mathrm{C} . \mathrm{FTIR}\left(\mathrm{KBr}, \mathrm{cm}^{-1}\right)$ :

$3238(\mathrm{OH}), 1625(\mathrm{C}=\mathrm{O}), 1591,1565($ ring $\mathrm{C}=\mathrm{C}),{ }^{1} \mathrm{H}$ NMR(500 MHz,DMSO $) \delta 5.31(\mathrm{~s}, 1 \mathrm{H},-\mathrm{OH}), \delta 6.88(\mathrm{~d}$, $\left.\mathrm{J}=16 \mathrm{~Hz}_{\mathrm{z}} 1 \mathrm{H}, \mathrm{H}_{\alpha}\right), \delta 7.67\left(\mathrm{~d}, \mathrm{~J}=16 \mathrm{~Hz}_{\mathrm{z}} 1 \mathrm{H}, \mathrm{H}_{\beta}\right), \delta 7.70-8.65(\mathrm{~m}, 9 \mathrm{H}, \mathrm{Ar}-\mathrm{H}), \delta 14.06(\mathrm{~s}, 1 \mathrm{H}, \mathrm{OH}) .{ }^{13} \mathrm{C}$ NMR (DMSO, 500MHz): $\delta 204.95(\mathrm{C}=\mathrm{O}), \delta 110.39-161.38\left(\right.$ Aromatic carbon).MS m/z:369(M $\left.{ }^{+}\right)$.Anal.Calc for $\mathrm{C}_{19} \mathrm{H}_{13} \mathrm{O}_{3} \mathrm{Br}: \mathrm{C}, 61.79 ; \mathrm{H}, 3.52 ; \mathrm{Br}, 21.68$.Found: $\mathrm{C}, 61.84 ; \mathrm{H}, 3.59 ; \mathrm{Br}, 21.74$.

3-(2, 4-Dichloro-phenyl)-1-(4-Bromo-1-hydroxyl-naphthalen-2-yl)-propenone (3h)

Brown solid, Yield, $74 \%$.Melting point, $211^{0} \mathrm{C} . \mathrm{FTIR}\left(\mathrm{KBr}, \mathrm{cm}^{-1}\right)$ : 3400(OH), 1621 (C=O),1590,1568(ring $\mathrm{C}=\mathrm{C}),{ }_{1}^{1} \mathrm{H}$ NMR(500 MHz,DMSO) $\delta 6.82\left(\mathrm{~d}, \mathrm{~J}=16 \mathrm{~Hz}_{\mathrm{z}} 1 \mathrm{H}, \mathrm{H}_{\alpha}\right)$, $\delta 7.41\left(\mathrm{~d}, \mathrm{~J}=16 \mathrm{~Hz}_{\mathrm{z}} 1 \mathrm{H}, \mathrm{H}_{\beta}\right), \delta 7.51-8.37(\mathrm{~m}, 8 \mathrm{H}, \mathrm{Ar}-\mathrm{H}), \delta 14.00(\mathrm{~s}, 1 \mathrm{H}, \mathrm{OH}) .{ }^{13} \mathrm{C}$ NMR (DMSO, $500 \mathrm{MHz}): \delta 204.75(\mathrm{C}=\mathrm{O}), \delta 110.22-161.55$ (Aromatic carbon).MS $\mathrm{m} / \mathrm{z}: 422\left(\mathrm{M}^{+}\right), 421,419,395,265,255,199,173,97$. Anal.Calc for $\mathrm{C}_{19} \mathrm{H}_{11} \mathrm{O}_{2} \mathrm{BrCl}_{2}: \mathrm{C}, 54.03 ; \mathrm{H}, 2.61 ; \mathrm{X}(\mathrm{Br}+\mathrm{Cl}), 35.78$.Found: $\mathrm{C}, 54.11 ; \mathrm{H}, 2.67 ; \mathrm{X}(\mathrm{Br}+\mathrm{Cl}), 35.82$.

3-(3-Nitro-phenyl)-1-(4-Bromo-1-hydroxyl-naphthalen-2-yl)-propenone (3i)

Yellow solid, Yield, $75 \%$.Melting point, $220^{\circ}$ C.FTIR $\left(\mathrm{KBr}, \mathrm{cm}^{-1}\right)$ : $3369(\mathrm{OH}), 1624(\mathrm{C}=\mathrm{O}), 1591,1567($ ring $\mathrm{C}=\mathrm{C}),{ }_{1}^{1} \mathrm{H}$ NMR(500 MHz,DMSO) $\delta 6.85\left(\mathrm{~d}, \mathrm{~J}=16 \mathrm{~Hz} 1 \mathrm{H}, \mathrm{H}_{\alpha}\right)$, $\delta 7.46\left(\mathrm{~d}, \mathrm{~J}=16 \mathrm{~Hz} 1 \mathrm{H}, \mathrm{H}_{\beta}\right), \delta 7.66-8.39(\mathrm{~m}, 9 \mathrm{H}, \mathrm{Ar}-\mathrm{H}), \delta 14.00(\mathrm{~s}, 1 \mathrm{H}, \mathrm{OH}) .{ }^{13} \mathrm{C}$ NMR (DMSO, $500 \mathrm{MHz}): \delta 204.61(\mathrm{C}=\mathrm{O}), \delta 110.00-161.77$ (Aromatic carbon.MS $\mathrm{m} / \mathrm{z}: 399\left(\mathrm{M}^{+}\right), 398,384,339,311,267,265,221$.Anal.Calc for $\mathrm{C}_{19} \mathrm{H}_{12} \mathrm{O}_{4} \mathrm{BrN}: \mathrm{C}, 57.29 ; \mathrm{H}, 3.02 ; \mathrm{Br}, 20.10 ; \mathrm{N}, 3.52$.Found: C,57.34;H,3.11;Br,20.10;N,3.58.

3-(4-Fluoro-phenyl)-1-(4-Bromo-1-hydroxyl-naphthalen-2-yl)-propenone (3j)

Yellow solid, Yield, $82 \%$.Melting point, $247^{0} \mathrm{C} . \mathrm{FTIR}\left(\mathrm{KBr}, \mathrm{cm}^{-1}\right)$ : $3432(\mathrm{OH}), 1625(\mathrm{C}=\mathrm{O}), 1606,1571$ (ring $\mathrm{C}=\mathrm{C}),{ }_{1}^{1} \mathrm{H} \mathrm{NMR}(500 \mathrm{MHz}, \mathrm{DMSO}) \delta 6.81\left(\mathrm{~d}, \mathrm{~J}=16 \mathrm{~Hz}_{\mathrm{z}} 1 \mathrm{H}, \mathrm{H}_{\alpha}\right)$, $\delta 7.44\left(\mathrm{~d}, \mathrm{~J}=16 \mathrm{~Hz} 1 \mathrm{H}, \mathrm{H}_{\beta}\right), \delta 7.67-8.37(\mathrm{~m}, 9 \mathrm{H}, \mathrm{Ar}-\mathrm{H}), \delta 13.99(\mathrm{~s}, 1 \mathrm{H}, \mathrm{OH}) .{ }^{13} \mathrm{C}$ NMR (DMSO, $500 \mathrm{MHz}): \delta 205.17(\mathrm{C}=\mathrm{O}), \delta 110.70-161.05$ (Aromatic carbon).MS $\mathrm{m} / \mathrm{z}: 371\left(\mathrm{M}^{+}\right), 339,325,281,265,255,181,97$.Anal.Calc for $\mathrm{C}_{19} \mathrm{H}_{12} \mathrm{O}_{2} \mathrm{BrF}: \mathrm{C}, 61.46 ; \mathrm{H}, 3.23 ; \mathrm{X}(\mathrm{Br}+\mathrm{F}), 26.69$.Found: $\mathrm{C}, 61.54 ; \mathrm{H}, 3.27 ; \mathrm{X}(\mathrm{Br}+\mathrm{F}), 26.75$.

3-(4-N-Dimethylamino-phenyl)-1-(4-Bromo-1-hydroxyl-naphthalen-2-yl)-propenone (3k)

Red solid, Yield, $84 \%$.Melting point, $162^{\circ} \mathrm{C} . \mathrm{FTIR}\left(\mathrm{KBr}, \mathrm{cm}^{-1}\right)$ : $3434(\mathrm{OH}), 1625(\mathrm{C}=\mathrm{O}), 1565,1503$ (ring $\mathrm{C}=\mathrm{C}),{ }^{1} \mathrm{H}$ NMR(500 MHz,DMSO) $33.72\left(\mathrm{~s}, 6 \mathrm{H}\right.$, two $\left.-\mathrm{CH}_{3}\right), \delta 6.78\left(\mathrm{~d}, \mathrm{~J}=16 \mathrm{~Hz} 1 \mathrm{H}, \mathrm{H}_{\alpha}\right), \delta 7.64(\mathrm{~d}, \mathrm{~J}=16 \mathrm{~Hz}$ $\left.1 \mathrm{H}, \mathrm{H}_{\beta}\right), \delta 7.67-8.68(\mathrm{~m}, 9 \mathrm{H}, \mathrm{Ar}-\mathrm{H}), \delta 14.00(\mathrm{~s}, 1 \mathrm{H}, \mathrm{OH}) .{ }^{13} \mathrm{C}$ NMR (DMSO, $500 \mathrm{MHz}): \delta 204.87(\mathrm{C}=\mathrm{O}), \delta 111.54-153.06($ Aromatic carbon).MS 
$\mathrm{m} / \mathrm{z}: 396\left(\mathrm{M}^{+}\right), 339,325,281,255,199,97$. Anal.Calc for

$\mathrm{C}_{21} \mathrm{H}_{18} \mathrm{O}_{2} \mathrm{BrN}: \mathrm{C}, 63.64 ; \mathrm{H}, 4.38 ; \mathrm{Br}, 20.20 ; \mathrm{N}, 3.54$.Found: C,63.69; H,4.44;Br,20.20;N,3.60.

3-(3, 4-Dihydroxy-phenyl)-1-(4-Bromo-1-hydroxyl-naphthalen-2-yl)-propenone (3l)

Brown solid, Yield, $79 \%$.Melting point, $180^{\circ} \mathrm{C}$.FTIR(KBr, $\left.\mathrm{cm}^{-1}\right)$ :

3431 $(\mathrm{OH}), 1625(\mathrm{C}=\mathrm{O}), 1592,1567($ ring $\mathrm{C}=\mathrm{C}),{ }^{1} \mathrm{H}$ NMR(500 MHz,DMSO) $85.18(\mathrm{~s}, 2 \mathrm{H}$,two $-\mathrm{OH})$, $\delta 6.81\left(\mathrm{~d}, \mathrm{~J}=16 \mathrm{~Hz}_{\mathrm{z}} 1 \mathrm{H}, \mathrm{H}_{\alpha}\right), \delta 7.42\left(\mathrm{~d}, \mathrm{~J}=16 \mathrm{~Hz}_{\mathrm{z}} 1 \mathrm{H}, \mathrm{H}_{\beta}\right), \delta 7.68-8.37(\mathrm{~m}, 8 \mathrm{H}, \mathrm{Ar}-\mathrm{H}), \delta 13.99(\mathrm{~s}, 1 \mathrm{H}, \mathrm{OH}) .{ }^{13} \mathrm{C}$ NMR (DMSO, 500MHz): $\delta 205.03(\mathrm{C}=\mathrm{O}), \delta 110.56-161.19$ (Aromatic carbon).MS $\mathrm{m} / \mathrm{z}: 385\left(\mathrm{M}^{+}\right), 377,325,283,265,249,165,97$.Anal.Calc for $\mathrm{C}_{19} \mathrm{H}_{13} \mathrm{O}_{4} \mathrm{Br}: \mathrm{C}, 59.22 ; \mathrm{H}, 3.38 ; \mathrm{Br}, 20.78$.Found: C,59.29; $\mathrm{H}, 3.41 ; \mathrm{Br}, 20.83$.

\section{3-(3, 4-Dimethoxy-phenyl)-1-(4-Iodo-1-hydroxyl-naphthalen-2-yl)-propenone (3m)}

Orange solid, Yield, $75 \%$.Melting point, $161^{0} \mathrm{C} . \mathrm{FTIR}\left(\mathrm{KBr}, \mathrm{cm}^{-1}\right)$ :

3432(OH), 1624(C=O),1586,1565(ring $\mathrm{C}=\mathrm{C}),{ }^{1} \mathrm{H}$ NMR(500 MHz,DMSO) $33.92\left(\mathrm{~s}, 6 \mathrm{H}\right.$,two $\left.-\mathrm{OCH}_{3}\right)$, $\delta 6.91\left(\mathrm{~d}, \mathrm{~J}=16 \mathrm{~Hz} 1 \mathrm{H}, \mathrm{H}_{\alpha}\right), \delta 7.35\left(\mathrm{~d}, \mathrm{~J}=16 \mathrm{~Hz} 1 \mathrm{H}, \mathrm{H}_{\beta}\right), \delta 7.51-8.38(\mathrm{~m}, 8 \mathrm{H}, \mathrm{Ar}-\mathrm{H}), \delta 13.98(\mathrm{~s}, 1 \mathrm{H}, \mathrm{OH}) .{ }^{13} \mathrm{C}$ NMR (DMSO, 500MHz): $\delta 204.28(\mathrm{C}=\mathrm{O}), \delta 110.38-164.65$ (Aromatic carbon), $\delta 76.84-85.70(\mathrm{C}-$

I), $855.99-56.19\left(\mathrm{O}_{-} \mathrm{CH}_{3}\right) \cdot \mathrm{MS} \mathrm{m} / \mathrm{z}: 460\left(\mathrm{M}^{+}\right), 459,312,311,97$. Anal.Calc for

$\mathrm{C}_{21} \mathrm{H}_{17} \mathrm{O}_{4} \mathrm{I}: \mathrm{C}, 54.78 ; \mathrm{H}, 3.70 ; \mathrm{I}, 27.61$.Found: C,54.82;H,3.77;I,27.68.

\section{3-(3, 4-Dihydroxy-phenyl)-1-(4-Iodo-1-hydroxyl-naphthalen-2-yl)-propenone (3n)}

Brown solid, Yield, $71 \%$.Melting point, $180^{\circ} \mathrm{C}$.FTIR $\left(\mathrm{KBr}, \mathrm{cm}^{-1}\right)$ :

3432(OH), 1624(C=O),1586,1565(ring $\mathrm{C}=\mathrm{C}),{ }^{1} \mathrm{H}$ NMR(500 MHz,DMSO) $55.20(\mathrm{~s}, 2 \mathrm{H}$,two $-\mathrm{OH})$, $\delta 6.78\left(\mathrm{~d}, \mathrm{~J}=16 \mathrm{~Hz}_{\mathrm{z}} 1 \mathrm{H}, \mathrm{H}_{\alpha}\right), \delta 7.29\left(\mathrm{~d}, \mathrm{~J}=16 \mathrm{~Hz}_{\mathrm{z}} 1 \mathrm{H}, \mathrm{H}_{\beta}\right), \delta 7.58-8.33(\mathrm{~m}, 8 \mathrm{H}, \mathrm{Ar}-\mathrm{H}), \delta 13.96(\mathrm{~s}, 1 \mathrm{H}, \mathrm{OH}) .{ }^{13} \mathrm{C}$ NMR (DMSO, 500MHz): $\delta 204.11(\mathrm{C}=\mathrm{O}), \delta 115.28-162.14$ (Aromatic carbon), $\delta 78.84-86.15(\mathrm{C}-\mathrm{I}) . \mathrm{MS}$ $\mathrm{m} / \mathrm{z}: 432\left(\mathrm{M}^{+}\right), 401,357,341,313,311,299,269,127,97$.Anal.Calc for $\mathrm{C}_{19} \mathrm{H}_{13} \mathrm{O} 4 \mathrm{I}: \mathrm{C}, 52.78 ; \mathrm{H}, 3.01 ; \mathrm{I}, 29.40$.Found: C,52.81;H,3.08;I,29.44.

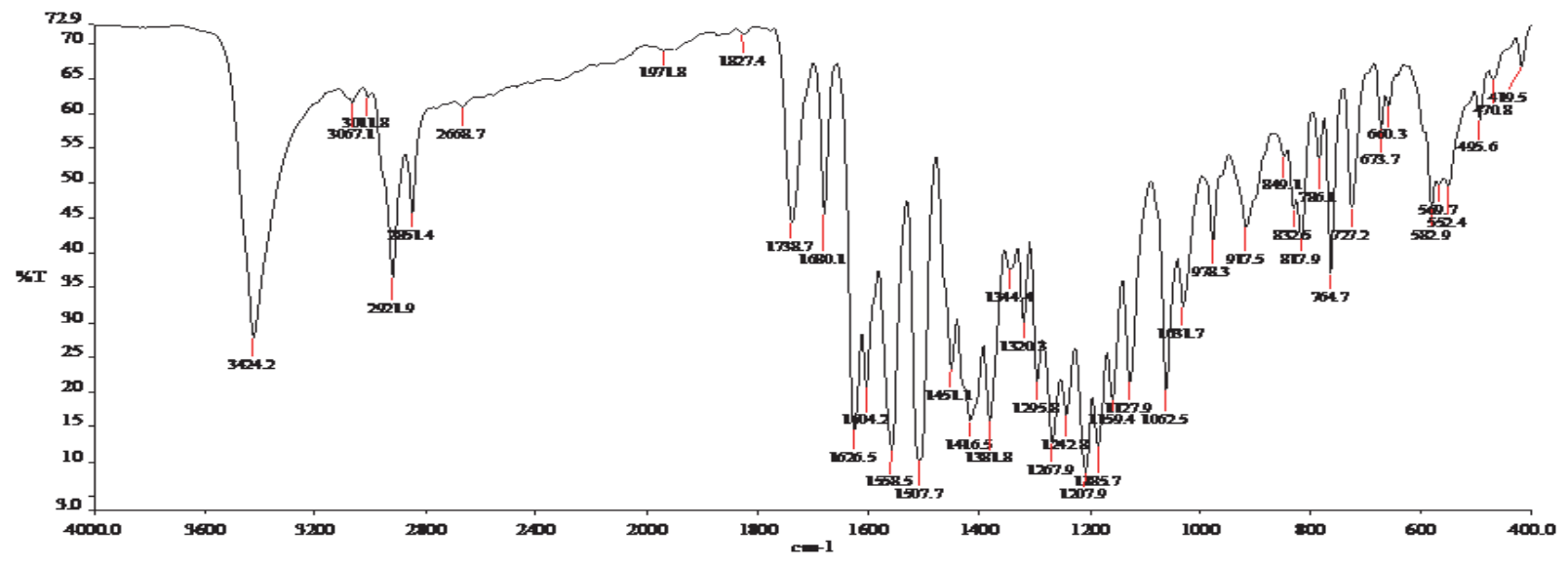

Fig. 4. IR spectrum of compound $3 d$ 


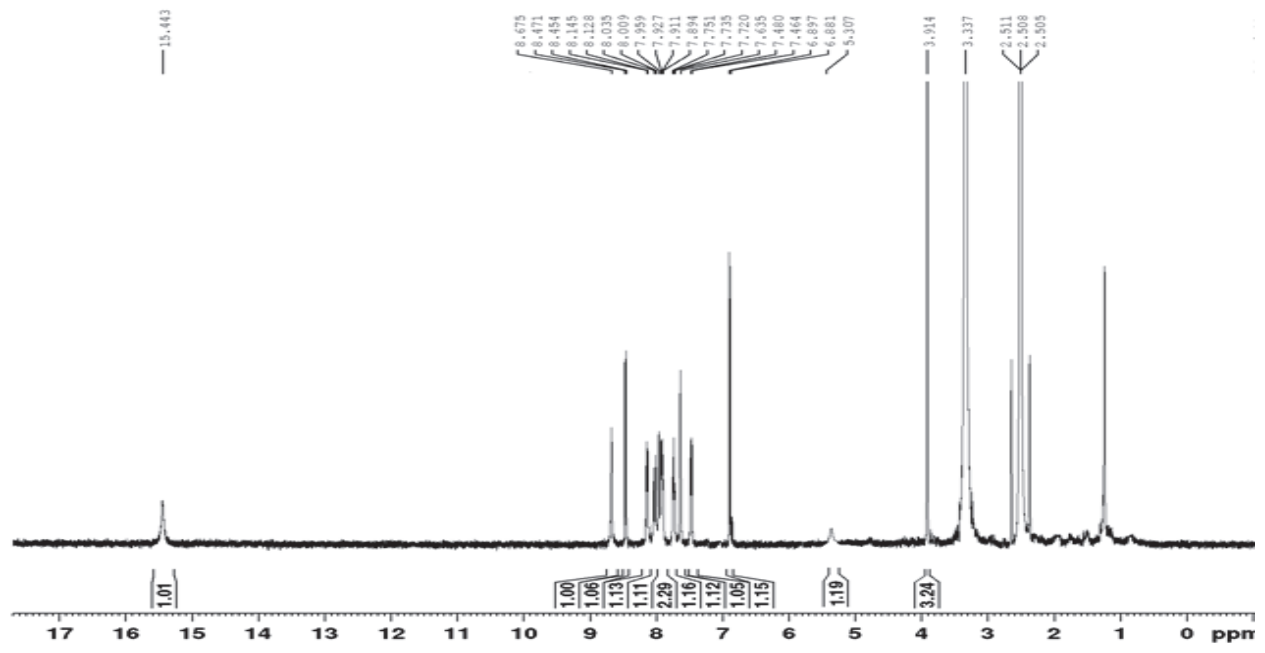

Fig. 5. ${ }^{1} \mathrm{H}$ NMR spectrum of compound $3 \mathrm{~d}$

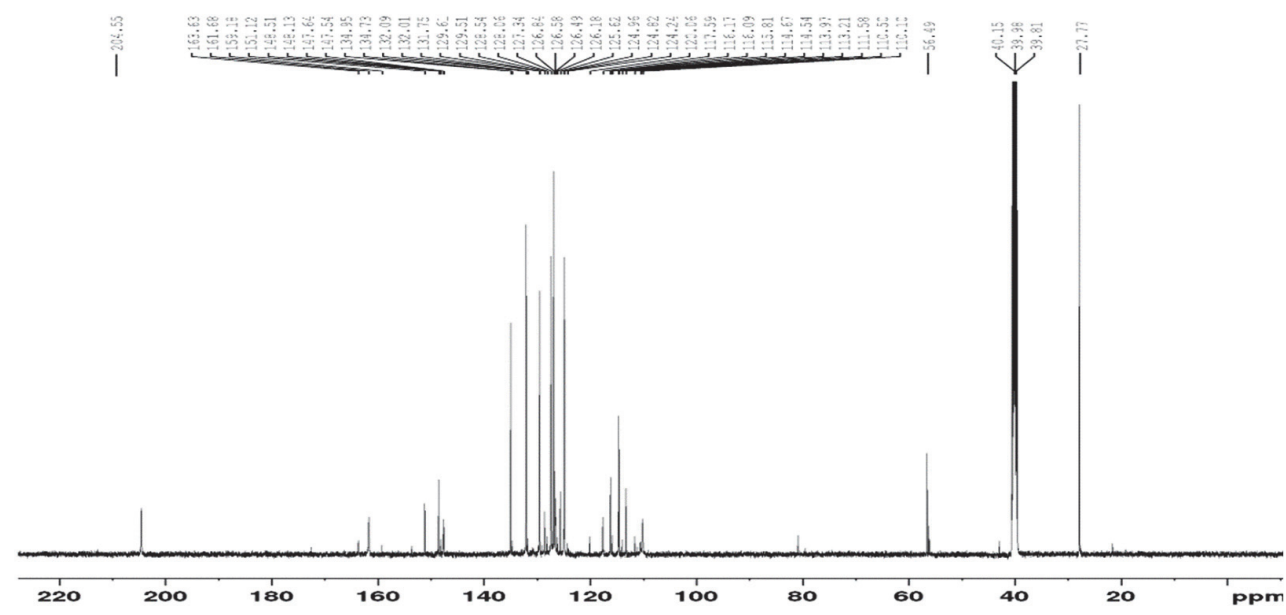

Fig. 6. $C^{13}$ NMR spectrum of compound $3 d$

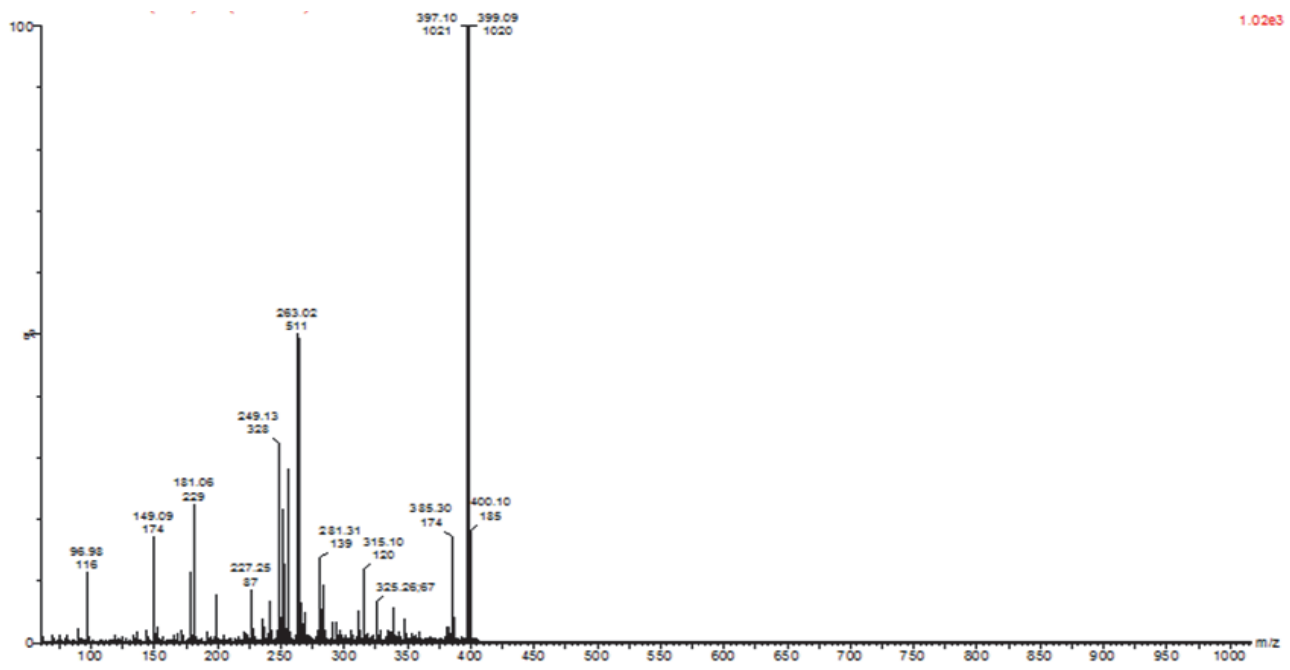

Fig.7. MS spectrum of compound 3d 


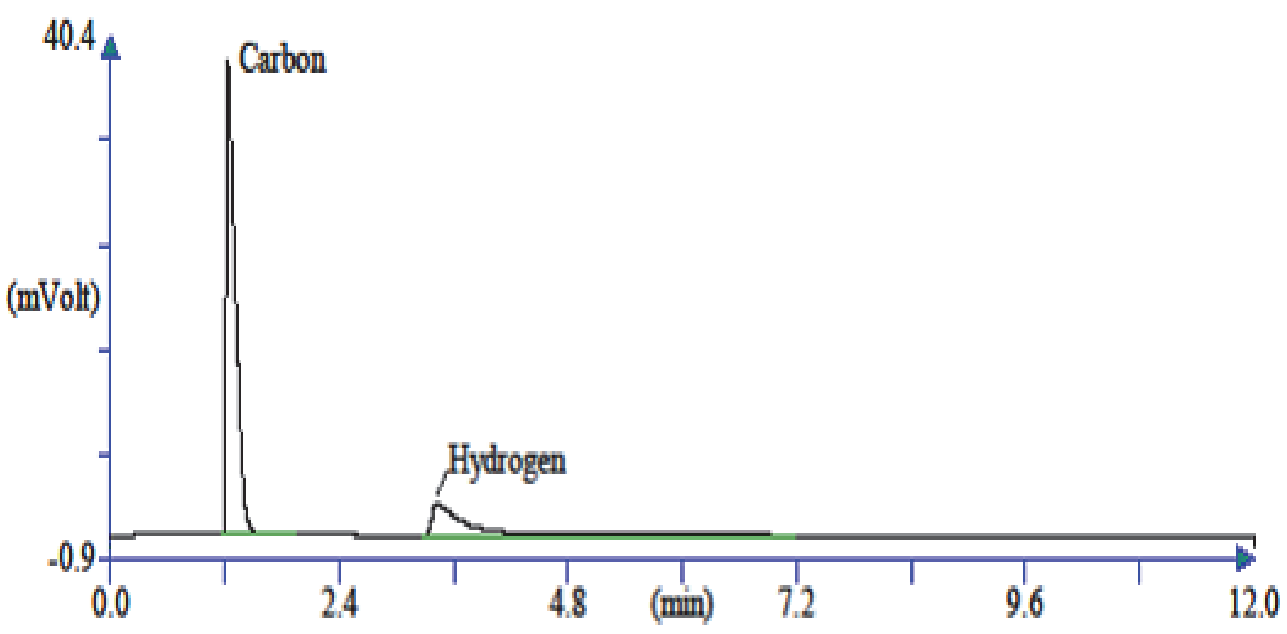

Fig. 8. CHN spectrum of compound $3 d$

\subsection{Cytotoxic activity}

Cytotoxic activity was screened against the organism Artemia salina for $24 \mathrm{hr}$ in-vitro assay. Sample solutions were prepared in dimethylsulfoxide (DMSO) solvent. Different sample concentrations such as $1 \mu \mathrm{M} / \mathrm{ml}, 10 \mu \mathrm{M} / \mathrm{ml}, 100 \mu \mathrm{M} / \mathrm{ml}$ and $1000 \mu \mathrm{M} / \mathrm{ml}$ were prepared from each compound. For the test, 96 well plates were used. In each test tube, $0.1 \mathrm{ml}$ of brine solution and 10 shrimps was added then treated with each sample solutions. For blank control, $0.1 \mathrm{ml}$ of brine solution and 10 shrimps was added in a test tube and well plates were incubated at room temperature $\left(28^{\circ} \mathrm{C}-30^{\circ} \mathrm{C}\right)$ under the condition of strong aeration for 24 hours. After incubation, nauplii were counted in the stem of capillary against light background. The percentage mortality was obtained by the following formula

Percentage mortality $=($ Total nauplii- alive nauplii $) /$ Total nauplii $\times 100$

\subsection{MTT Assay for the compounds $3 \boldsymbol{a}, \mathbf{3 b}, \mathbf{3 f}, \mathbf{3 h}$ and $\mathbf{3 l}$.}

Liver cancer cell line (HepG2) was cultured at concentration $10^{4}$ cells per well in $100 \mu 1$ culture medium in 96 well flat bottom microplates overnight. Control wells were incubated with DMSO $(0.2 \%$ in PBS) and cell line. Various sample concentrations of each compound such as $200 \mathrm{mg} / \mathrm{ml}, 400 \mathrm{mg} / \mathrm{ml}$, $600 \mathrm{mg} / \mathrm{ml}, 800 \mathrm{mg} / \mathrm{ml}$ and $1000 \mathrm{mg} / \mathrm{ml}$ were prepared in dimethylsulfoxide. All samples were incubated in triplicate. Controls were maintained to determine the control cell survival and the percentage of live cells after culture. Cell cultures were incubated for $24 \mathrm{~h}$ at $37^{\circ} \mathrm{C}$ and $5 \% \mathrm{CO}_{2}$ in $\mathrm{CO}_{2}$ incubator. After incubation, medium was removed completely and added $20 \mu 1$ of MTT reagent ( $5 \mathrm{mg} \mathrm{mL}^{-1}$ in PBS) to each well. Then cells were incubated for $4 \mathrm{~h} 37^{\circ} \mathrm{C}$ and $5 \% \mathrm{CO}_{2}$ in $\mathrm{CO}_{2}$ incubator. The resulting formazan crystals were dissolved in $200 \mu \mathrm{l}$ DMSO and absorbance was measured spectrophotometrically at $550 \mathrm{~nm}$ after 10 minute incubation at $37^{\circ} \mathrm{C}$. The inhibition induced by each tested compound at indicated concentrations was calculated by the following formula.

$\%$ inhibition $=$ Control absorbance-test absorbance $/$ control absorbance

\subsection{In-vitro Antimicrobial Screening}

In vitro antimicrobial screening of the compounds were performed for their antibacterial and antifungal activities by Agar cup plate method. Amipicilin and fluconazole were used as standard for antibacterial and antifungal activities respectively. Stock solutions $(1 \mathrm{mg} / \mathrm{ml})$ of all the compounds and 
standards were prepared in dimethylsulfoxide. From the stock solutions, $100 \mu \mathrm{l}$ of volume was used to inoculate.

The gram positive bacterial slant Staphylococcus aureus (ATCC6538) and gram negative bacterial slant Echerchia coli (ATCC8739) were incubated with growth media Soyabean casein digest agar in incubator at condition $35^{\circ} \mathrm{C}$ for $24 \mathrm{hr}$. The fungal slant Candida albicans (ATCC10231) was incubated with growth media sabourauds dextrose agar in incubator at condition $25^{\circ} \mathrm{C}$ for $72 \mathrm{hr}$. After incubation, picked up the well grown slant and inoculated in saline solution and vortexes to uniform suspension. Adjusted the O.D. of the culture with saline water at $530 \mathrm{~nm}$ on calorimeter and at viable count was $1 \mathrm{x}$ $10^{7}$ colony forming unit $(\mathrm{CFU} / \mathrm{ml})$. These culture suspensions were inoculated on Mueller-Hinton agar, and plates were bored by cork borer $(6 \mathrm{~mm})$ to create wells. Added a volume of $100 \mu 1$ of sample solution in to each well. Two controls were maintained for each test. These included reference drug control and blank control. Then plates were incubated for bacteria at $35^{\circ} \mathrm{C}$ for $24 \mathrm{hrs}$ and for the yeast and mould incubated at $25^{\circ} \mathrm{C}$ for $48 \mathrm{hrs}$ to examine the zone of inhibition. All the experiments were performed in triplicate and the average zone of inhibition was reported.

\subsection{Minimum inhibitory concentration (MIC)}

The Staphylococcus aureus, Echerchia coli and Candida albicans suspension was prepared after incubation of each slant for $24 \mathrm{hrs}$ in incubator. O.D. of the culture was earlier adjusted at $1 \times 10^{7}$ colony forming unit $(\mathrm{CFU} / \mathrm{ml})$. The determination of minimum inhibitory concentrations of the synthesized compounds was carried by agar dilution method. Various serial dilutions of synthesized compounds 1 $\mathrm{mg} / \mathrm{ml}, 0.5 \mathrm{mg} / \mathrm{ml} .0 .25 \mathrm{mg} / \mathrm{ml}$ and $0.12 .5 \mathrm{mg} / \mathrm{ml}$ were prepared in dimethylsulfoxide. $1 \times 10^{7}$ cells were inoculated on Mueller-Hinton agar, and then plates were punched by cork borer $(6 \mathrm{~mm})$ to create wells. The volume $100 \mu \mathrm{l}$ of various sample concentrations were added in to the well. Then plates were incubated for bacteria at $35^{\circ} \mathrm{C}$ for $24 \mathrm{hrs}$ and for the yeast and mould incubated at $25^{\circ} \mathrm{C}$ for $24 \mathrm{hrs}$ to examine the zone of inhibition. Two controls that is, one with reference standard and other without standard or test was maintained for each test. By visual inspection, the lowest concentration of test solution with no detectable bacterial growth was considered as minimum inhibitory concentration.

\section{References}

1. Sarada S.R., Jadhav W.N., Bhusare S.R., Wasmatkar S.K., Dake S.A., Pawar R.P. (2009) Solvent-free $\mathrm{NaOH}-\mathrm{Al}_{2} \mathrm{O}_{3}$ supported synthesis of 1, 3-diaryl-2-propene-1ones.Inter.J.Chem.Tech.Res. 1(2) 265-269.

2. Asiri A.M., Khan S.A. (2011) Synthesis and antibacterial activities of a bis-chalcone derived from thiophene and its bis-cyclized products. Molecules 16(1) 523-531.

3. Kakati D., Sarma J.C. (2011) Microwave assisted solvent free synthesis of 1, 3diphenylpropenones. Chem. Cen. J. 5(8) 1-5.

4. Zangade, S., Chavan, S., Vibhute, A., Vibhute, Y. (2011) Synthesis and studies on antibacterial activity of some new chalcones and flavones containing naphthyl moiety. Sch. Res. Lib. 3(5) 20 27.

5. Saini, R. K., Choudhary, A. S., Joshi,Y.C., Joshi, P. (2005) Solvent free synthesis of chalcones and their antibacterial activities. E-J. Che. 2(4) 224-227.

6. Wang, K., Li, Y., Zhang, Li-J., Chen, Xiao-G., Feng, Zhi-Q. (2014) Synthesis and in vitro cytotoxic activities of sorafenib derivatives Chin. Chem. Lett. 25(5) 702-704.

7. Bandgar, B.P., Gawande, S.S., Bodade, R.G., Totre, J. V., Khobragade, C.N. (2010) Synthesis and biological evaluation of simple methoxylated chalcones as anticancer, anti-inflammatory and antioxidant agents. Bioorg. Med. Chem. 18(3) 1364-1370.

8. Vogel, S., Ohmayer, S., Brunner, G., Heilmann, J. (2008) Natural and non-natural prenylated chalcones: Synthesis, cytotoxicity and antiodidative activity. Bioorg. Med Chem. 16(8) 42864293. 
9. Kateb B.A., Hussien A.A.Basser M.A. (2016) Microwave-Assisted efficient synthesis of ortho hydroxyl chalcones as probes for biological activities.IJPPR 6 (1) 210-217.

10. Sanal D.,Sunil R.D. (2013) A solvent-free protocol for the green synthesis of heterocyclic chalcones.Sch.Res.Lib. 5 (5) 219-223.

11. Prasad Y.R., Rao A.L., Rambabu R.,Ravikumar P. (2007) Synthesis and biological evaluation of some novel chalcone derivatives.Ori.J.Che.23(3) 927-937.

12. Rao M.S., Kotesh J., Narukulla R., Duddeck H. (2004) Synthesis and spectroscopic characterization of some chromanochalcones and their dihydro derivatives.ARKIVOC. 2004 (xiv) 96-102.

13. Bhuiyan M.M.H., Hossain M.I., Mahmud M. M., Al-Amin M. (2011) Microwave assisted efficient synthesis of chalcones as probes for antimicrobial activities. Chem.J. 1(1) 21-28.

14. Singh J.P., Dulawat M., Jaitawat N., Chundawat S., Devpura A., Dulawat S.S. (2012) Microwave enhanced Claisen-Schmidt condensation: A green route to chalcones. Ind.J.Chem., 51B, 16231627.

15. SrivastavaY.K. (2008) Ecofriendly microwave assisted synthesis of some chalcones. Ras.J. Chem. 1 (4) 884-886.

16. Calvino V., Picallo M., Lopez-peinado A.J., Martin-aranda R.M, Duran-valle C.J. (2006) Ultrasound accelerated claisen-schimdt condensation: a green route to chalcones. App.Sur.Sci., 252(17) 6071-6074.

17. Zangade S., Mokale S., Vibhute A., Vibhute Y. (2011) An efficient and operationally simple synthesis of some new chalcones by using grinding techinque. Che. Sci. J., 2011(CSJ-13) 1-6.

18. Senthilkumar G., Neelkandan K., Mankandan H. (2014) A convenient, green, solvent free synthesis and characterization of novel fluorochalcones under grind-stone chemistry. Pel.Res.Lib. 5(2) 106-113

19. Raten N.M., Zohdi H.F. (2009) Atom-efficient, solvent-free, green synthesis of chalcones by grinding.Syn.Comm. 39(15) 2789-2794.

20. Piste P. (2014) Synthesis of chalcones by grindstone chemistry as an intermediate in organic synthesis.I.J.Curr.Sci. 13(E) 62-66.

21. Eddarir, S., Catelle, N., Bakkour, Y., Ranlando, C. (2003) An efficient synthesis of chalcones based on the Suzuki reaction. Tetrahedron Letters. 44(28) 5359-5363.

22. Petrov O., Ivanova Y.,Gerova M. (2008) $\mathrm{SOCl}_{2} / \mathrm{EtOH}$ : Catalytic system for synthesis of chalcones.Cat.Comm. 9(2) 315-316.

23. Macquarrie D., Nazih R., Sebti S. (2002) KF/natural phosphate as as efficient catalyst for synthesis of 2'-hydrocychalcones and flavonones. Green Chem.4(1) 56-59.

24. Pore D. M., Desai U. V., Thopate T. S., Wadgaonkar P. P. (2007) Efficient synthesis of chalcones at room temperature in the presence of Potassium phosphate. Rus.J.Org. Chem. 43(7) 1088-1089.

25. Shntaif A.H. (2016) Green synthesis of chalcones under microwave irradiation.Int.J.Chem.Tech.Res. 9(2) 36-39.

26. Zhang Z.,Dong Y.W.,Guan W.U.,Wang G.W. (2003) Efficient and clean aldol condensation catalyzed by sodium carbonate in water.Chem.Lett. 32(10) 966-967.

27. Sebti S., Solhy A., Smahi A., Kossir A. Oumimoun,H.(2002) Dramatic activity enhancement of natural phosphate catalyst by lithium nitrate: An efficient synthesis of chalcones.Cat.Comm.3(8) 335-339.

28. Thirunarayanan G.,Vanangamudi G., (2006) Synthesis of some 4-bromo-1-naphthyl chalcones using silica-sulfuric acid reagent under solvent free conditions. ARKIVOC.2006(xii) 58-64.

29. Kshatriya R. B., Machhi J. K., Nazeruddin G.M., (2014) Novel methodology and process optimization for the synthesis of flavones.Int.J.Pha.Res.Rev. 3(2) 47-57.

30. Ali M. F., Khlafulla A. M. (2016) Friendly and efficient synthesis of chalcone derivatives under solvent free condition.Res.Rev.J.Pha. 6 (1) 1-8.

31. Palleros D.R. (2004) Solvent free synthesis of chalcones. J. Che. Edu. 81(9) 1345-1347.

32. Unchadkar A., Zangade S., Shinde A., Deshpande M. (2015) Microwave assisted synthesis of some halo substituted chalcones. J. Tur.Che.Soc. 2 (1) 1-8. 
33. Shinde, A.T., Zangade, S. B., Chavan, S.B., Vibhute, A.Y., Nalwar, Y.S., Vibhute. Y. B. (2010) A practical iodination of aromatic compounds by using iodine and iodic acid. Syn.Commu. 40 (23) 3506-3513.

34. Giles, R.G.F., Green, I.R., Knight, L.S., Son, V.R.L., Mitchell, P.R.K., Yorke, S.C. (1994) Regioselecive bromination, debromination and bromine migration in a 2-acetoxymethyl-4, 5, 7trialkoxynaphthalene.J.Che.Soc.Per.Tra.1.7853-857.

35. Saikia, I., Borah, A.J., Phukan, P. (2016) Use of bromine and bromo organic compounds in organic synthesis. Che. Rev. 116(12) 6837-7042.

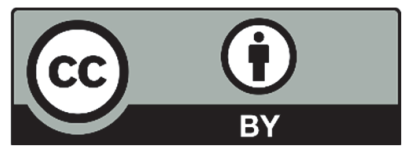

(C) 2020 by the authors; licensee Growing Science, Canada. This is an open access article distributed under the terms and conditions of the Creative Commons Attribution (CC-BY) license (http://creativecommons.org/licenses/by/4.0/). 